\title{
Storytelling and Sustainability Reporting: An Exploratory Study of Leading US Retailers
}

\author{
By Peter Jones* \\ Daphne Comfort ${ }^{\dagger}$
}

\begin{abstract}
Stories, in one form or another, are probably as old as the human race, but in recent years, businesses have increasingly come to recognise the importance of storytelling. The aim of this paper is to offer an exploratory review of storytelling within the sustainability reports published by the leading US retail companies. The paper begins with an outline of the characteristics of storytelling within the corporate world, reviews the ways storytelling is employed in some of the major US retailers' most recent sustainability reports and offers some reflections on current approaches to storytelling in sustainability reporting within the retail sector of the economy. The paper identifies a number of storytelling formats, including photographs, cameo case studies, impact stories and video clips, used by the leading US retailers. However while such stories often have a strong human impact and can strike emotive chords, the authors would argue that stories can be, at least partly, misleading in that they do not necessarily fully reflect a retailer's sustainability record.
\end{abstract}

Keywords: Stories, Storytelling, Sustainability Reports, US Retailers.

\section{Introduction}

Storytelling - defined as the cultural and social activity of sharing stories is probably as old as the human race and is certainly much older than recorded history. The forms, meanings and contexts of storytelling have changed over time, but in recent years businesses have increasingly come to recognise the strategic importance of storytelling. Gupta (2015), for example, argued that 'stories are an effective tool in the strategy process and for communicating and achieving strategic objectives' and PricewaterhouseCoopers (2017) suggested that 'storytelling is one of the most powerful tools available to effective communicators.' More specifically Johansen and Nielsen (2012) explored how storytelling can contribute to corporate social responsibility (CSR) and GarciaRosell (2017) examined 'the possibilities and challenges of using stories as vehicles for critically evaluating contemporary business practices and testing the moral and political boundaries of CSR.' Gill (2015) argued that 'stories have been shown to be a natural medium to represent an organisation's significance, values and mission.' Within the retail sector of the economy the US Retail Industry Leaders Association, whose membership includes Walmart, Target, Home Depot, JC Penney, Gap, Lowe's and Costco, concluded its most

\footnotetext{
* Professor of Management, The Business School, University of Gloucestershire, UK.

${ }^{\dagger}$ Research Administrator, The Business School, University of Gloucestershire, UK.
} 
recent Retail Sustainability Management Report (Retail Industry Leaders Association 2017a) by identifying storytelling as one of the four key ingredients for corporate success in pursuing, and reporting on, sustainability programmes.

Corporate sustainability reporting had its origins in the 1960's and 1970's in Europe, and slightly later in the US, but some traditional large retailers claim that sustainability has always been an integral part of their core values, while others have adopted sustainable principles more recently. Within the last three decades, sustainability has certainly been gathering momentum throughout the retail industry. Within the US, Home Depot, for example, claimed to be the first retailer to establish a set of environmental principles in 1991, the US Retail Industry Leaders Association's sustainability initiatives originated in 2007, though its first sustainability report did not appear until 2012, and Wal-Mart produced its first annual sustainability report in 2008. At the same time a range of studies have examined the sustainability strategies and achievements of major players within the industry (e.g. Jones et al. 2005, Jones et al. 2011, Wiese et. al. 2012, Delai and Takahashi 2013). However, with the exception of a conference paper by Frostenson et al. (2012), the role of storytelling in retailers' sustainability reports has received little or no attention in the academic literature. With these thoughts in mind, the aim of this paper is to offer an exploratory review of storytelling within the sustainability reports published by the leading US retail companies. The paper begins with an outline of the characteristics and role of storytelling within the corporate world, reviews the ways storytelling is employed in the major US retailers' most recent sustainability reports and concludes by offering some reflections on current approaches to storytelling in sustainability reporting within the retail sector of the economy.

\section{Storytelling and Sustainability in the Business and Retail World}

Storytelling has its roots in the origins of human civilisation and has traditionally been used to share, and pass on, knowledge, values, myths, legends, fables and religious beliefs, from one generation to another and across geographical space. Initially storytelling was conducted though drawings and word of mouth communication though over time the written, and then the printed, word became an increasingly important storytelling medium. More recently, developments in information and communication technologies, particularly social media, have seen storytelling become an increasingly all pervasive and all embracing experience. In many ways, stories inform and illuminate all walks of life and in recent years, storytelling has become increasingly important in the corporate business world and in many of the sub disciplines of business and management.

At the macro level Gill (2015) defined 'corporate storytelling' as 'the process of developing and delivering an organisation's message by using narration about people, the organisation, the past, visions for the future, social bonding and work itself, in order to create new point-of-view or reinforce an opinion or behaviour.' While Hutchinson (2017, p. 69) recognised the 'growing 
importance of stories' he argued that 'storytelling to date has found a more lukewarm reception in business school education.' Nevertheless, at the sub discipline level, in the financial world, for example, Markey-Towler (2017) claimed that 'governments and investors ignore the power of storytelling at their peril. The financial markets are not driven by interest rates and money alone. They are driven by one of the most ancient traditions of humanity stories. We can lead an investor to liquidity but we can't make them drink without telling them a story about why it is so very tasty.' Savita et al. (2011) recognised that storytelling in knowledge management is a powerful management tool, and in exploring the role of storytelling in the context of information systems. Weissenfeld et al. (2017) argued that storytelling is used in order to transport a complex content more vividly to the audience and to ensure that the audience remembers the content as long as possible.' Kent (2015) argued 'storytelling is a staple of public relations, from crisis to branding, to identity to reputation.' In emphasising the importance of storytelling in marketing, Hammond (2017) argued that 'storytelling is a strategy that brands utilize in order to help their target audiences not only learn about their products and services but also to form an emotional connection that will lead them to remain loyal to their company for years to come.'

A number of benefits have been claimed for storytelling within the business world. Storytelling is seen to be important in linking a wide range of business challenges and opportunities to everyday human experiences and in helping to generate emotional connections with companies and in giving them a human face. Many good, arguably the best, stories are memorable and thus not only the story itself but also the message behind the story can help to sustain positive views of a business and its operations and behaviours. Stories can be important in disseminating and sharing a company's values, which may be built on founding philosophies and past achievements, and in helping to enhance these values in future business development trajectories. More specifically stories can be important not only in developing awareness and understanding of a company's values and commitments to a wide range of stakeholders, but also in helping to engender stakeholders' trust in these values and commitments. Ultimately, and ambitiously, there is the belief that stories can be inspirational and that they can have the power to encourage and stimulate changes in behaviour. In summarising the benefits of 'corporate storytelling', Gill (2015) suggested that 'stories can be used in organisations as a means to motivate people and create a message memorable enough for people to take cause and action, if there is an identified interest to the listener.' Further Gill (2015) claimed that stories have 'universal appeal to culturally diverse audiences who have a range of interests and learning styles.'

Within the retail world storytelling has long been used to enable retailers to forge strong relationships with their customers. Here storytelling is seen to be important in that it enables retailers to forge strong bonds with their customers and for customers to feel connected to the retail brand. As such, storytelling is seen to be vitally important in conveying what the retail brand stands for, and the provenance of that brand and its goods and services. At the 
same time, storytelling can not only educate, entertain and engage but also appeal to customers' emotions. Social media plays an increasingly important part in the storytelling process in that it encourages customers to take an active role in sharing retail experiences. Academic research into the role of storytelling in retailing has been limited but an experimental study by Gilliam and Zablah (2013) suggested that product stories told from a business point of view were likely to be most effective in influencing customers' purchasing intentions in one time sales encounters. More generally, Gilliam et al. (2014) identified a number of dimensions of retail storytelling, including story relevance, story humour and storytelling ability and explored how they influenced consumer behaviour.

While stories have long been a feature of retail sales and consumer buying behaviour in recent years, storytelling has also become an important element in how a growing number of companies communicate with their stakeholders on sustainability. Diesendorf (2000) argued that 'sustainability' can be seen as 'the goal or endpoint of a process called sustainable development.' The most widely used definition of sustainable development is 'development that meets the needs of the present without compromising the ability of future generations to meet their own needs' (World Commission on Environment and Development 1987). Richardson (2008: 47) argued that while 'the advent of Triple Bottom Line sustainable business concept has gained credence featuring in academic, consultancy and practitioner texts' retail academics have 'not prioritised sustainability' (Richardson 2008: 53). This view might be seen to have been confirmed in a review of sustainability in retailing undertaken by Wiese et al. (2012 p.318), where the authors found that 'sustainability has received more attention in retail management practice compared to research applications.' However just three years later Wiese et al. (2015: 298) identified a number of emerging trends and directions' within a structured framework for 'sustainability research within retailing.'

The growing interest in and commitment to sustainability has seen the widespread emergence of sustainability reporting within the retail sector of the economy. In reviewing 'the state of play in sustainability reporting' van Wensen, Broer, Klein and Knofp (2011) argued that 'sustainability reporting is the provision of environmental, social and governance information within documents such as annual reports and sustainability reports.' More specifically, in a case study of a large Swedish retailer entitled 'Sustainability Reporting as Negotiated Storytelling' Frostenson et al. (2012) revealed that 'the sustainability reporting process is characterised by negotiations between internal constituents to define the best story of the corporation's sustainability impact.' Within the US the Retail Industry Leaders Association's Retail (2017b) Sustainability Leadership Management Model, designed to 'identify possible pathways to strong environmental sustainability programs in retail', emphasised the importance of storytelling in addressing the visibility of the sustainability reporting process.

Further, the Retail Industry Leaders Association argued that storytelling was important in reporting and communicating as well as in point of purchase consumer education and in marketing campaigns. In addressing the role of 
storytelling in reporting and communicating, for example, the Retail Industry Leaders Association (2017b) charted five stages, on the spectrum of 'sustainability management maturity' namely 'initiating, progressing, excelling, leading and transforming.' In the initiating stage, for example, a 'regularly published report contains cursory mention of sustainable practices' or 'some limited sustainability/ corporate social responsibility information is available on (corporate) website.' In the excelling stage, 'sustainability goals (are) publicly articulated and tracked' and there is 'a balanced and honest discussion of challenges as well as progress' while the 'transforming stage includes a 'focused multi-channel reporting sustainability campaign with features such as an interactive sustainability website.' At the same time the Retail Industry Leaders (2017b) pointed out that the five stages were possible pathways to sustainability optimization' and that not every company can, or will, progress through all five stages.

\section{Reference Frame and Enquiry Method}

In an attempt to obtain an exploratory review of the ways storytelling is employed in the major US retailers' most recent sustainability reports, the top ten US country of origin retailers (Deloitte 2017), as measured by retail revenue, namely Wal-Mart, Costco, Kroger, Walgreens Boots Alliance, Home Depot, Amazon, Target, CVS Health, Lowe's and Albertsons, were selected for study. As the largest, and arguably amongst the dominant players, within the retail industry within the US, the selected companies might be seen to reflect cutting edge and innovative approaches to sustainability reporting within the sector and thus to be employing storytelling as part of the reporting process. While three of the selected companies only have retail operations within the US, the others operate within a number of countries, Wal-Mart, for example have operations in 30 countries and the corresponding figures for Walgreens Boots Alliance, Costco and Lowe's are 10, 10 and 4 respectively, though all the top ten US country of origin retailers have global supply chains. As such, all the selected retailers' sustainability reports ideally should be addressing international, as well as domestic, agendas in their sustainability reports.

While retailers have employed a range of methods to report on their sustainability commitments and achievements, publication on corporate websites has become the most popular and the most accessible reporting mechanism (Morhardt 2009). With this in mind, the authors conducted an Internet search for information, using the key phrase 'sustainability report' and the name of each of the selected US retailers. This search was conducted in October 2017, using Google as the search engine, and the most recent reports for each of the selected companies obtained from this search process provided the empirical information for this paper. All of the leading US country of origin retailers, apart from Amazon, posted sustainability reports on the Internet, though the nature and content of the sustainability reporting process varied considerably. 
Some of the selected companies, including Wal-Mart, Home Depot and Walgreens Boots Alliance posted traditional linear style reports while the sustainability reports posted by Costco, Kroger and Target contained linked highlights which expanded their readability. The traditional sustainability reports varied considerably in length. The Wal-Mart report contained 198 pages while the corresponding figures for Home Depot, and Target, and Walgreens Boots Alliance were 101, 53 and 44 respectively.

In reviewing the selected retailers' sustainability reports the authors were essentially guided by loose grounded theory. More specifically, given they were looking to explore how human interest was being integrated into sustainability reporting, they pursued an interpretivist approach in that they selected and grouped the general content of the selected sustainability reports into five broad elements namely mission, vision and strategy statements; graphics; metrics; general structured narrative; and specific storytelling. The storytelling elements provided the empirical material for this paper. The specific examples and selected quotations drawn from the storytelling elements are used for illustrative purposes, with the principal aim being on reviewing the ways storytelling is employed in the major US retailers' most recent sustainability reports. The focus is not on providing a comparative evaluation of how the leading US retailers employed storytelling within their sustainability reports or on looking to place individual retailers on the Retail Industry Leaders Association's sustainability management maturity spectrum. Unless specifically cited all quotations are drawn from the selected companies' sustainability reports.

The paper is based on information that is in the public domain and the authors took the considered view that they did not need to contact the selected companies to obtain formal permission prior to conducting their research. When outlining the issues of reliability and validity in relation to information drawn from the Internet, Saunders et.al. (2009) emphasised the importance of the authority and reputation of the source and the citation of a specific contact individual who might be approached for additional information. In reviewing the sustainability reports, the authors were satisfied that these two conditions were met. At the same time the authors recognise that their study has its limitations not least in that it includes just nine of the leading US retailers and that it is based on authors' designation and interpretation of the storytelling elements in those nine retailers' sustainability reports. That said the authors believe that their approach offers is appropriate in what is an exploratory study.

\section{Findings}

All the selected US retailers employed storytelling to illustrate their strategic commitments and their environmental, social and economic achievements in their sustainability reports, though there were marked variations in the extent to which stories were used. A number of themes can be identified. Photographs were the most widely used method to tell a story within the reports and they were employed in a variety of ways. In his Introduction to the Home Depot report, 
for example, Craig Menear, the company's Chairman, Chief Executive Officer and President, was accompanied by a photograph of him in a store wearing a bib apron bearing the company's name and the slogans 'I put customers FIRST', 'More Saving' and 'More Doing.' Later on in the report, a message from Ron Jarvis, the company's Vice President for Environmental Innovation, was accompanied by a photograph of him, also in store, and bearing a bib apron bearing the slogan 'I help in all Departments.' A photograph of Robert A. Niblock, Chairman, President and Chief Executive Officer of Lowe's showed him in store wearing company apparel to accompany his introductory message, in the company's sustainability report. Here the story is that not only do senior executives have hands on contact with the everyday retail environment and that in so doing they emphasise the company's commitment to its customers and emphasises some of the company's values.

Photographs are also widely used to illustrate a number of social, economic and environmental themes within the selected retailers' sustainability reports. In reporting on its support for the reintegration of US veterans into the civilian workforce, Wal-Mart, for example, used two photographs. The one a smiling young female in a military uniform bearing the US flag and the other a smiling male company employee holding a picture of himself in his military uniform. These two photographs illustrated the human dimensions to a general narrative in which Wal-Mart reported on having offered employment to 162,000 veterans and promoted more than 20,000 veterans to roles of greater responsibility since 2013. Elsewhere in the Wal-Mart sustainability report, a photograph of two smiling employees from Frey Farms in Illinois', holding a cabbage in front of a field of cabbages, was used to accompany the company's claim to be supporting local and small farmers. A photograph of two smiling shopkeepers in their store was used to illustrate the company's claim to support the growth of small businesses. Here again the underlying message emphasised the human dimensions of the company's commitment to sustainability. More generally, within the selected companies' sustainability reports, photographs were used to help to illustrate the companies' commitments to investing in well-being, to helping young people and families to build life-long healthy habits, to harnessing solar energy and to helping customers make recycling a way of life.

Costco employed a series of photographs to illustrate its more general narratives outlining the company's 'sustainability commitment' to its employees and its communities as well as to how it incorporated its sustainability principles and responsibilities into its operations and merchandising activities. These photographs were designed to provide positive images of the company. They depicted smiling employees in company uniforms, well-stocked and busy stores, a smiling group of children from two elementary schools who had received backpacks on the first day at school from the company and of a palm oil plantation to illustrate the company's commitment to the responsible and sustainable sourcing of palm oil. In a similar vein, CVS Health used a photograph of a tree landscape alongside an outline of a brief description of how it identified the material issues seen to be relevant in defining the content 
of its sustainability report and a photograph of two young children walking in a field alongside a statement of the company's core commitment to 'helping people on their path to better health.'

Many of the selected retailers use cameo case studies as part of their approach to storytelling. In addressing environmental issues, Lowe's, for example, illustrated its approach to recycling and waste with a small case study of a 'Take Back program at 350 of its RONA stores.' This programme provides the opportunity for customers to return products for recycling and the case study reported that in 2016 the stores recycled some 7 million pounds of paint, and collected 220,000 pounds of batteries and 20,000 pounds of power tool accessories. This programme was extended to the company's Orchard stores in 2016. A small case study of Lowe's achievements in pursuing product sustainability focused upon sustainable forest management. The case study included details of the company's 'Wood Products Procurement Policy' and its support for forest biodiversity and conservation. The case study was endorsed by the following quotation by Jules Foisy-Lapointe, Corporate Social Responsibility Director for Lowe's Canada, 'we are excited to share learning and best practices to further elevate our commitment to environmental and product sustainability.' A case study was also used to illustrate Lowe's commitment to 'public engagement and conversation.' The company is a charter member of the Boreal Business Forum and the case study described its collaborative work with the Canadian provincial governments, forest product companies, environmental groups and First Nation peoples, to address the health and well-being of caribou herds.

A number of the selected retailers reported on their work in supporting local communities and enhancing resilience in the face of environmental disasters, and cameo case studies have been employed to provide details of specific initiates. Albertsons, for example, included a case study of flood relief in Louisiana. The case study told the story of how within two days of the first rains, the company's stores in Louisiana launched an instore fundraising campaign for the American Red Cross Louisiana Flood Relief campaign and that Albertsons matched public donations up to $\$ 300,000$. The company also arranged food donations to the Baton Rouge Food Bank and its store in Denham Springs, one of the areas hardest hit by the flooding, served as an emergency shelter and command station for city officials and the Fire and Police departments. In a similar vein the Wal-Mart sustainability report contained cameo case studies of how the company had helped provide relief following the destruction wrought by Hurricane Matthew in 2016 as well as its work in disaster relief in Guatemala, China and Argentina.

Cameo case studies were also used by a number of the selected companies to illustrate social and economic sustainability achievements. Under the banner 'Empowering Women in our Workforce' Target, described how the company was 'working to engage and advance women in Science, Technology, Engineering and Math careers through two unique programs.' The first, 'Target Women in Science and Technology' is 'an internal organisation that fosters connections, inspiration and knowledge sharing' while the second 'Women in Engineering 
and Science at Target', which was launched in 2016, looks 'to encourage connections within the female tech community and organisations near Target headquarters.' Walgreens Boots Alliance employed four simple case studies, accompanied by photographs, to summarise its '2016 Corporate Social Responsibility Highlights.' One tells the story of a lady, who is one of over 900 company employees who identify as people with disabilities. The lady has worked as a general warehouse worker in one of the company's distribution centres. Her manager reports that 'the job has transformed her life' while the lady herself said 'this job has allowed me to be more independent in what I do. The benefits are huge. I had no benefits before I started. I had no life insurance. This job has helped me financially.' Another of the case studies focused on a small child in Guatemala who receives twice yearly vitamin supplements, provided by Walgreens Boots Alliance, at her school.

Wal-Mart's sustainability report included 25 'Impact' stories ranging across the company's environmental, social and economic sustainability agendas and achievements. Here the overarching message of the stories was on how Wal-Mart could make a difference to environments, resource use and people's lives. Under the banner 'Increasing Economic Opportunity and Inclusion', for example, there was a story of how one of the company's departmental mangers 'graduates to her next step.' The story is of a first generation immigrant from India who joined Walmart as the backroom worker unloading vehicles and stocking inventory, then moved to work with customers on the shop floor and registered on the company's development and training programme, before being promoted to manage a department within the store. Another 'Impact' story described how Wal-Mart had been supporting small and medium sized farmers in Brazil through its 'Producers Club.' The story told how over 7,400 growers, throughout the country, were involved in supplying a range of produce, including lettuce and tomatoes, to Wal-Mart, who also help farmers to strengthen their production and marketing techniques. The company claim that their interventions not only allow Wal-Mart 'to put fresh local produce on its shelves' but also to 'make a real difference in the lives of individual farmers.'

In addressing environmental issues Wal-Mart also used an 'Impact' story to report on 'working with communities to preserve wetlands.' The story described how the company donated a 3-acre wetland site to the city of Logan, in Utah, that was created in the course of building a large Wal-Mart store. The wetland was constructed to mitigate the impact to small streams on the property and provides a buffer and habitat for local plants and wildlife. In another 'Impact' story, and under the headline 'Project Coconut', Wal-Mart outlined its achievement in finding a better way to clean up oil spills at its gas stations. Traditionally the clay based materials that were used to clean up such spills produced waste that had to be sent to hazardous waste incinerators or to special landfill sites. The development of a new coconut based natural absorbent, has removed the need for special waste treatment and more positively the waste can now be used to power cement kilns and other industrial facilities and the company reported that they hope to turn some 275,000 pounds of absorbent into usable fuels. 
The sustainability reports posted by two of the selected companies, namely Kroger and Costco, included linked video material as part of their storytelling. Kroger, for example, used short linked video clips to illustrate over 30 of its environmental and social sustainability commitments. With the title 'We're All in the Same Boat' Kroger used a one minute video clip sequence of marine life, fishing boats and fish products in stores, with a musical accompaniment and subtitles, to describe how the company had supported over 20 fisheries improvement projects throughout the world during the past decade. Linked video clips were also employed to showcase Kroger's long standing 'Zero Hunger Zero Waste' campaign which supports over 200 food banks within the US, and its employee healthcare support programme, community support and community reward initiatives, its local sourcing policies and its waste treatment programmes. Costco provided a link to an external video clip that illustrated how volunteers from the company were involved in providing food for the homeless and clothes for families in need within the communities around their stores.

\section{Discussion}

Increasingly storytelling is seen to be important in bringing corporate sustainability reporting to life and the findings reported above reveal that storytelling is certainly playing a part addressing a range of environmental, social and economic agendas and achievements in the sustainability reports posted by the leading US retail companies. That said a number of issues merit discussion and reflection. Firstly, the vast majority of the stories cited above certainly have a strong human dimension and many of them strike a potentially powerful emotive chord. The tone of the stories is exclusively positive in painting the retailers' general sustainability strategies, and more particularly their specific policies, actions and achievements in a good light. As such the stories reflect Leinaweaver's (2015) claim that 'many corporate sustainability reports have perfectly scripted stories - stories told to create a party line.' Within the social realm stories featuring employees, for example, paint a picture of a committed and caring employer, of the provision of a wide range of development opportunities within the workplace and of a happy and loyal workforce. In a similar vein stories about the retailers' commitment to the communities in which they operate are very much within the spirit of community building or fostering resilience and community rebuilding in areas hit by natural disasters. A common thread running through stories with an environmental theme is a commitment to stewardship and to the conservation of natural resources. This, in turn, might be seen to signal recognition amongst leading retail corporations that while the earth's natural resources are being consumed at an unsustainable rate, sustainability stories 'can actually be a source of inspiration for further growth' (Storytelling People 2017).

However, the underlying message in all the retailers' sustainability stories stands in marked contrast to a number of very different stories about the environmental, social and economic activities of large corporate retailers and to 
long standing anti-corporate retailer campaigns (Jones et al. 2006). There have been a number of largely single issue and localised protests against many large US retailers, including, for example, a campaign by Greenpeace calling on Home Depot to cancel its logging contracts with companies cutting timber in British Columbia's Great Bear Rainforest (Greenpeace 2017) and protests by animal rights groups about animal welfare at Costco suppliers (JaneUnchahined. com 2017) but the most sustained and wide-ranging campaigns have been waged against Walmart.

The campaigns against Wal-Mart have embraced a number of issues including concerns about predatory pricing, the exercise of monopoly power over suppliers, the generation of a range of problems in communities, attendant upon the opening of a Wal-Mart store, concerns about employees' wages and working conditions within the US and about workers and working conditions at overseas suppliers as well as a number of environmental issues. The Fall 2017 edition of 'Making Change at Walmart' e-newsletter (changewalmart.org 2017), for example, stressed the importance of holding the largest retailer in the world, Walmart, accountable' and pledged to 'continue the fight for justice at Walmart - the fight for better pay and working conditions, the fight for improved employer-provided health care and the fight for respect and dignity on the job.' In 2013, a report published by the Institute for Local Self Reliance, claimed 'Walmart ranks as one of the biggest and fastest growing climate polluters in the country' and argued that 'Walmart lags its peers in making the shift to renewable power, its progress hamstrung by an unwillingness to accept a very modest reduction in profits for more investment in solar and wind systems' (Mitchell 2013). The vast majority of the allegations and concerns cited above are fiercely contested by the named retailers but they present a very different image of the corporate retail world to that portrayed in the stories many of the large US retailers employ in their sustainability reports.

Secondly there are issues surrounding the relationship between the 'particular' and the 'general' in that the stories within the sustainability reports posted by the selected retailers focus on particular individuals and events, presumably specially chosen and choreographed by the selected retailers. As such these stories may well have a strong human interest attraction, and many of them certainly have a strong emotive appeal, which may well resonate with audiences on corporate websites and social media, but they cannot necessarily be seen to be representative of a retailer's sustainability agendas and achievements. Indeed, more cynically, the leading retailers might be seen to be taking the view that such stories may play a valuable role in directing attention away from concerns being expressed in both the mainstream media, on pressure group publications and websites and on social media about retailers' activities. That is not, of course, to call into question the voracity and/or the integrity of the stories themselves but rather to suggest that retailers' sustainability reports need to address how they draw up their sustainability strategies and agendas and on how they are able to verify the achievements they report. Here the key issues are materiality and independent external assurance. 
Materiality is concerned with how the environmental, social and economic sustainability issues that are deemed to be most important to the company, and crucially to all its stakeholders, are determined. Three of the nine selected retailers who produced sustainability reports, namely, Kroger, Costco and Albertsons provide no information on stakeholder engagement while a further three, namely, Wal-Mart, Home Depot and Lowe's offered some limited information on how stakeholder engagement contributed to the assessment of how stakeholders perceive the sustainability challenges facing these companies. Only three of the selected retailers, namely, Lowes, Target and Boots Walgreens Alliance, provided a full outline of the materiality process undertaken to identify and prioritize the key issues that, in turn, informed the details of the reporting process. Target, for example, listed 33 internal and external stakeholders engaged as part of this process and then provided details of the identification, assessment and validation actions taken to define and translate material environmental, social and economic issues into its approach to sustainability. The focus on materiality in the selected US retailers' sustainability reports clearly varied. In the absence of information to the contrary, the identification of material issues by some of the selected retailers might be seen to represent the executive management's thinking and to favour corporate business continuity goals, rather than to reflect the potentially wider concerns of the company's other internal, and many external, stakeholders. As such, the stories used to illustrate a number of the sustainability issues identified in the selected retailers' sustainability reports might be also be seen to reflect strategic corporate thinking rather than wider stakeholder concerns.

Within the business community commissioning independent external assurance of the information contained in corporate sustainability reports is becoming an increasingly common element within the reporting process. However only one of the selected US retailers, Walgreens Boots Alliance, included an assurance report in its sustainability report. This assurance exercise, conducted by Deloitte, focused on some 21 environmental, community and workplace indicators within the sustainability report. More, generally external assurance merited little or no mention in the sustainability reports posted by the other selected retailers. CVS Health reported that the company did not have a formal policy for external assurance but that it did use a third party to verify its greenhouse gas emissions inventory. Here again while specific stories were used to illustrate many of the environmental, social and economic issues in the selected retailers' sustainability reports, their more general applicability might be seen to be called into question by the lack of independent external assurance.

Thirdly, and more generally, in many ways the US retailers' sustainability reports reviewed in this paper, are both traditional and conservative in style in that there is, at best, only a limited attempt to harness rapidly evolving developments in information and communication technologies in the reporting process. Amesheva (2017), for example, suggested that technological innovations that 'enable real-time data collection and reporting, new methods of communication and number-crunching is set to transform the world of corporate social responsibility.' In a similar vein Morin and Muruganathan (2017) argued 
that new developments in information and communication technologies offer 'creative ways to share sustainability stories' and to create 'real human stories for a wide audience.' More specifically, Morin and Muruganathan (2017) suggested that companies can now 'liberate the content in their sustainability reports', for example, by improved accessibility, the development of engaging content, digital videos and documentaries and data visualisation tools. However how far many large companies will choose to go in embracing such innovations and in effectively providing wholesale and transparent public access to sustainability data remains very much to be seen. That said such innovations will surely provide exciting new vehicles for storytelling within sustainability reports and such innovatively presented stories may find a receptive audience amongst many stakeholders who are increasingly conscious of, and receptive to, sophisticated methods of communication and reporting. Such an approach may allow companies to illustrate their sustainability achievements with seemingly compelling stories that seem so seductive and vivid that they effectively mask the bigger, and possibly less appealing picture.

\section{Conclusions}

Storytelling has grown in importance within the world of business and it is now commonly employed, for example, in public relations, communications management and marketing. More specifically stories are increasingly used as an integral element of corporate sustainability reporting. This paper reviews the ways stories have been used in the sustainability reports published by some of the leading retailers within the US and identifies a number of storytelling formats, namely, photographs, cameo case studies, impact stories and video clips. While such stories can offer a powerful human appeal and can strike emotive chords, the authors would argue that stories can be, at least partly, misleading in that they do not necessarily fully reflect, a retailer's sustainability record. More contentiously, positive stories with a potentially powerful emotive human appeal might be seen to mask a more accurate record of a company's sustainability achievements. That said Sutton's (2017) argument, that there is no role for storytelling in sustainability reports, might be considered extreme and seems unlikely to find favour amongst large investors, employees, consumers, the media, governments and pressures groups, as well as academic commentators, look to rigorously review corporate sustainability reports and the sustainability reporting process. Here the issues of materiality and external assurance might be seen to loom large if the storytelling elements within sustainability reports are to seen to have credibility and validity in accurately reflecting a retailer's strategic approach to sustainability. More specifically, retailers may wish to ensure that the stories they employ in their sustainability reports are reflect the concerns of a wide range of the company's stakeholders and that the more general themes that such stories illustrate are externally assured. At the more everyday level retailers might also give consideration to selectively using such 
sustainability stories in product displays and at focal points and checkouts within their stores.

The authors recognise that this exploratory paper has a number of limitations, as outlined earlier, but they believe not only that it provides an initial commentary on storytelling in the sustainability reports posted by the leading US retailers but that, as such, it also provides a platform for future research. Looking to the future academic research might profitably include studies of how other retailers, possibly in different parts of the world, employ storytelling within their sustainability reports and of the stages and processes involved in identifying and developing sustainability stories within retail companies. At the same time future research might also be profitably undertaken into customers' perceptions of sustainability stories, particularly if they are displayed within stores, and of if, and how, such stories influence store patronage and buying behaviour

\section{References}

Amesheva I (2017) Five technology trends in defining the future of corporate sustainability. Eco-Business. Retrieved from http://bit.ly/2wNOUJb. [Accessed 6 November 2017].

Changewalmart.org (2017) Making Change at Walmart (2017) Fall 2017 e-newsletter.

Available at http://bit.ly/2Esk1Zd. [Accessed 15 February 2018].

Delai I, Takahashi (2013) Corporate sustainability in emerging markets: insights from the practices reported by Brazilian retailers. Journal of Cleaner Production 47: 211-231.

Deloitte (2017) Global Powers of Retailing. Retrieved from http://bit.ly/2qgAc7M. [Accessed 23 October 2017].

Diesendorf M (2000) Sustainability and sustainable development. In D Dunphy, JA Beneveniste, A Griffiths, P Sutton (eds) Sustainability: The Corporate Challenge of the $21^{\text {st }}$ Century, 19-27. Sydney: Allen and Unwin.

Frostenson M, Helin S, Sandstrom J (2012) Sustainability Reporting as Negotiated Storytelling. Retrieved from http://bit.ly/2Cmyd3Z. [Accessed 23 October 2017].

Garcia-Rosell J-C (2017) Corporate Social Responsibility Learning Through Collaborative Storytelling. Retrieved from http://bit.ly/2o1SU0Z. [Accessed 24 October 2017].

Gill R (2015) Why the PR strategy of storytelling improves employee engagement and add value to CSR: an integrated literature review. Public Relations Review 41: 662-674.

Gilliam DA, Zablah AR (2013) Storytelling during retail sales encounters. Journal of Retailing and Consumer Services 20: 488-494.

Gilliam DA, Flaherty KE, Rayburn SW (2014) The dimensions of storytelling by retail salespersons. International Review of Retail, Distribution and Consumer Research 24: 242-251.

Gupta, M. (2015) How Strategic Leaders Use Storytelling. Retrieved from http://bit.ly/ 2HjaGoq [Accessed 24 October 2017].

Greenpeace (2017) Greenpeace Protests Home Depot's Profit from Destruction of Ancient Rainforests. Retrieved from http://bit.ly/2CnElZD. [Accessed 5 November 2017]. 
Hammond K (2017) Storytelling in Your Marketing Efforts. Retrieved from http:// www.business2community.com/marketing/importance-using-storytelling-marke ting-efforts-01831875\#YeSmy3K6qtSLCYum.97 [Accessed 24 October 2017].

Hutchinson K (2017) Stories and storytelling for small business leaders. In K Hutchinson (ed) Leadership and Small Business, 1-9. London: Palgrave Macmillan.

JaneUnchained.com (2017) Animal Rights Group Protests Costco Over Suppliers Pig Treatment with Virtual Reality Tools. Available at http://bit.ly/2BwPJ8L. [Accessed 5 November 2017].

Johansen TS, Nielsen AE (2012) CSR in corporate storytelling- legitimacy as a question of differentiation and conformity. Corporate Communications: An International Journal 17: 434-448.

Jones P, Comfort D, Hillier D, Eastwood I (2005) Retailer and sustainable development in the UK. International Journal of Retail and Distribution Management 33: 207-214.

Jones P, Comfort D, Hillier D (2006) Anti-corporate retailer campaigns on the internet. International Journal of Retail and Distribution Management 34: 882-891.

Jones P, Comfort D, Hillier D (2011) Sustainability in the global shop window. International Journal of Retail and Distribution Management 39: 256-271.

Kent ML (2015) The power of storytelling in public relations: introducing 20 master plots. Public Relations Review 41: 480-489.

Leinaweaver J (2015) Storytelling for Sustainability: Deepening the Case for Change. Abingdon: Routledge.

Markey-Towler B (2017) How Storytelling Drives Finance and Economics. Retrieved from http://bit.ly/2kM1RLr. [Accessed 24 October 2017].

Mitchell S (2013) Walmart's Assault on the Climate. Retrieved from http://bit.ly/2EF DRn4. [Accessed 5 November 2017].

Morhardt JE (2009) Corporate social responsibility and sustainability reporting on the internet. Business Strategy and the Environment 19: 436-452.

Morin I, Muruganathan K (2017) Innovation in Sustainability Reporting: New Design Trends and Digital Solutions for Powerful Storytelling. Retrieved from http:// www.eco-business.com/opinion/innovation-in-sustainability-reporting-new-desi gn-trends-and-digital-solutions-for-powerful-storytelling/ [Accessed 23 October 2017].

PricewaterhouseCoopers (2017) Storytelling in Business. Retrieved from http://bit.ly/ 2F7e9pq. [Accessed 24 October 2017].

Retail Industry Leaders (2017a) Retail Sustainability Management Report 2017. Retrieved from http://bit.ly/2EusmQ7. [Accessed 24 October 2017].

Retail Industry Leaders Association's Retail (2017b) Sustainability Leadership management Model. Retrieved from http://bit.ly/2HiVRSD. [Accessed 31October 2017].

Richardson N (2008): To what extent have key retail and generic marketing texts adopted sustainability? World Journal of Retail Business Management 2: 47-55.

Saunders M, Lewis P, Thornhill A (2009) Research Methods for Business Students. Harlow: Prentice-Hall.

Savita KS, Hazwani H, Kalid KS (2011) The development of a narrative management system: storytelling in knowledge management. International Journal of Computer and Information Engineering 5: 262-266.

Storytelling People (2017) Corporate Storytelling. Retrieved from http://bit.ly/2Bv1xZd. [Accessed 3 November 2017].

Sutton J (2017) Why There Is No Role for Storytelling in Your Sustainability Report. Retrieved from http://bit.ly/2pIx7dC. [Accessed 3 November 2017]. 
van Wensen K, Broer W, Klein J, Knofp J (2011) The State of Play in Sustainability Reporting in the European Union. Retrieved from http://bit.ly/2HdaqHj. [Accessed 4 April 2016].

Wiese A, Kellner J, Lietke B, Toporowski W, Zielke S (2012) Sustainability in retailing a summative content analysis. International Journal of Retail \& Distribution Management 40: 318-335.

Wiese A, Zielke S, Toporowski W, (2015) Sustainability in retailing- research streams and emerging trends. International Journal of Retail and Distribution Management 43: 293-300.

Weissenfeld K, Abramova O, Krasnova H (2017) Understanding Storytelling in the Context of Information Systems. Retrieved from http://bit.ly/2GbVQ1m. [Accessed 25 October 2017].

World Commission on Environment and Development (1987) Our Common Future. Retrieved from http://www.un-documents.net/ocf-02.htm. [Accessed 30 July 2014]. 